\title{
Application of Behavioral Ecology to Aquaculture and Resource Management in Crab Fisheries
}

\author{
五嶋聖治 \\ 北海道大学大学院水産科学研究科. $\bar{\tau} 041-8611$ 函館市港町 3-1-1 \\ Seiji GOSHIMA \\ Graduate School of Fisheries Sciences, Hokkaido University. Hakodate 041-8611, Japan
}

\begin{abstract}
Japanese crab fisheries for king crabs (Paralithodes spp.), snow crab (Chionoecetets opilio), and hair crab (Erimacrus isenbeckii), have declined in recent years. Various fishing regulations have been adopted to increase and maintain the stocks for these fisheries, however they have been ineffective. Here I propose behavioral ecological approaches that might help increase crab stocks through aquaculture and resource management, particularly through seed production at hatcheries and resource management of wild stocks. I present three case examples: 1) the operational sex ratio at crab hatcheries, 2) determination of male maturity size in the wild, and 3) resource management of wild crab stocks. Male crabs guard ripe females for several days before mating. This guarding behavior results in a great physiological cost for males. In such mating systems, a female-biased operational sex ratio, which is often observed in space-limited hatcheries, may reduce the potential reproductive ability of females. A more even operational sex ratio should be maintained to improve reproductive success in crab hatcheries. In the wild, male maturity should be determined based on the functional (behavioral) maturation size (defined as the size at which copulation begins), and size limits for fishing should be based upon on functional maturity. Selective fishing for larger male crabs, which is a common practice in these fisheries, may lead to female biased stocks on the fishing grounds. Removing the functionally mature males may lead to a serious depression in crab productivity by reducing the number of viable males available for copulation with recently molted receptive females. Furthermore, smaller male crabs usually have a lower fertilizing ability due to their small amounts of sperm (sperm limitation). Therefore, fishing regulations in large decapod fisheries should be enacted that ensure effective reproduction in order to realize the potential spawning capacity of unfished females. These examples illustrate that behavior-ecology approaches can be effective in the conservation of crab populations, and should be more frequently applied to crab aquaculture and fisheries.
\end{abstract}

Key Words: behavioral ecology, crab, fishery, mate guarding, operational sex ratio, reproduction, resource management, seed production

\section{はじめに}

行動生態学が明確な学問体系として日本に導入されたの は，今から 20 年ほど前のことである（Krebs \& Davies 1981; 日本語訳（城田・上田訳）は 1984 年に出版). 新たな行動 生態学の考え方によって, それまで種の存続のためと思わ れてきたさまざまな動物の行動が，わが子，あるいは自分 の持つ遺伝子を数多く残すために懸命に生きている表れで あると解釈できるようになった，当時，その斬新な考え方 に強く影響を受けた若い生態学研究者は少なくなかった。 その後この分野は大きく発展し, 日本にも専門の学会がで

Received 4 Mar. 2002 Accepted 13 Apr. 2002
き(日本動物行動学会, 1982 年設立), 行動生態学はさま ざまな分類群と分野に根づいた。

行動生態学は水産增殖, あるいは栽培漁業という応用分 野とは一見してかけ離れた学問体系のように思われる。し かし，栽培漁業や水産增殖が生きた水生動植物を対象と し, その過程の重要な部分に, 生物が本質的に持つ特徴で ある再生産して子孫を残すという繁殖過程が大きく関わっ ている限り, 行動生態学と無縁であるはずがない. 繁殖の メカニズムは, 行動生態学がもっとも得意とする研究分野 のひとつなのである.

ケガニ Erimacrus isenbeckii, タラバガニ Paralithodes camtschaticus などの大型甲殼類は, 漁業生産の中では量的 には多くはないものの, 根強い需要があり各地で盛んに漁 獲されている。しかし, 個体数の減少や漁獲サイズの小型 化など，資源減少の兆候を示す例が多く，漁獲量は長期的 
に低迷しているのが現状である（農水省北海道統計情報事 務所 2000)，資源量増大と安定生産のために漁獲規制等の 資源管理が試みられているが，その成果は必ずしも期待ど 扮りではない。さまぎまな方面からのアプローチによって 資源の回復と保全を検討する必要がある。ここでは漁業と いう応用分野には一見無縁に思える行動生態学が, 大型甲 殼類の栽培漁業や資源管理に有効であるということを，八 ナサキガニ Paralithodes brevipes や小型種ではあるものの同 じタラバガニ科に属するイボトゲガニ Hapalogaster dentata を例に話を進めたい。

\section{大型甲殼類の繁殖生態}

水産生物の幼稚仔や未成体を放流する種苗放流は, 直接 的に資源量増大をはかる策として多用されており，大型甲 款類においてもその効果が期待されている。つくり育てる 栽培漁業は, 健全な親の確保から受精・産卵, 幼生・稚仔 の育成, 中間育成，種苗放流，そして漁獲といった一連の プロセスからなる。健全な種苗の生産がその後の中間育成, 放流後の成長や生残に大きく影響し，ひいては栽培漁業の 成否を左右する (北島 1993 など)。そのため, 健全な種苗 の生産とその効率化のためにさまざまな工夫が講じられて いるが，まだまだ改良の余地があるようである。対象種の 繁殖生態をきちんと把握するという基本的なことが重要で あるが，そのためには，対象種そのものとともに，扱いゃ すい類縁種をモデル種として研究を進めることも大事であ る。ここでは夕ラバガニ類 Lithodidae と, その類縁種であ るホンヤドカリ類 Paguridaeの繁殖生態の類似性を見てみ よう.

\section{繁殖行動}

ハナサキガニは千島列島, サハリン, シベリア沿岸, 北 海道ではオホーツク海沿岸, 襟裳岬から根室半島にかけて の太平洋沿岸に局所的に分布するタラバガニ科の異尾類で ある．国内の漁獲量は年間 100 トン前後でそれほど多くは ないものの, ケガニ, タラバガニとならんで北海道を代表 する大型甲殼類として人気がある。長期的な漁獲量低迷を 打破すべく，資源回復のために種苗放流事業が行われてい る。種苗生産は北海道厚岸町にある日本栽培漁業協会厚岸 事業場が中心となって行っている.

繁殖期になると，オスが両方のはさみ脚で産卵間近（脱 皮直前）のメスのはさみ脚，あるいは歩脚をつかんだり， 自分の体で覆いかぶさるガード行動が観察される (Fig. 1). メスの交尾可能な時間が短く限定されていて, メスの発見 効率が低い場合には, 前もってメスを確保して拉き，他の オスを追い払い，自分の精子のみが受精に使われて我が子 を残すのに有利であるために，このような交尾前ガード行 動が進化したと考えられている (Ridley 1983; 山村 1986). このガード行動はメスが産卵するまで続く。この間，メ久
は目立った動きはほとんど示さずにじっとしていることが 多い、メスが脱皮した直後に両者は交尾し，ただちにメス は産卵する。産卵が終了すると, 数日間続いたペアを解消 して而者は別机る (詳細は Wada et al. 2000 を参照).

同じ水槽内にいる成熟オスの交尾回数は, 相対的な体サ イズに依存し, 大型オスほど交尾回数が増加する。その要 因はオス同士の争いに見ることができる。ガード行動中の ペアに割って人り，メスを奪㧍うとするケースでは, 压倒 的に大型オスが有利である。この観察結果から容易に想像 つくように，大型オスの方がガード行動を遂行しやすく, 繁殖成功率が高まる結果となる (Wada et al. 1997). 加えて, あまりに小型のオスはメスにガードを拒絶されることも， 小型オスの繁殖がうまくいかない一因である。

産卵まぢか(脱皮直前) の成熟入スを戈そらくは性フ土 ロモンを感知することによって識別し，はさみ脚でメスの 体の一部をはさみ持つという甲殼類のガード行動は, 魚類 などに多く見られる放卵・放精するだけの繁殖システムと 比較して, オスにとっては時間的にもエネルギー的にもコ ストがかかる行動にちがいない。なにしろ，オスはガード 期間中の $3 ， 4$ 日間は全く摂食せず，ひたすらメスの体を 持ち続け，時々やってくるライバルオスとメスの奪い合い になることもしばしばある。そして, 相手メスが脱皮し, 交尾して産卵完了までガードし続けるのである、それほど 時間と体力を必要とするガード行動は，ひとえにオスに とってわが子を残したいというオス側の事情による（山村 1986 など).

メスにとっても，敵に対しておそらくは最も無防備な脱 皮時期にオスにガードしてもらえるのは利益があるに違い ない。もちろん，相手はどんなオスでもよいというわけで はなく，メスにはメスの事情がある。たとえば，ガード中 のオス同士の争いでは強い大型オスが有利となり，大型才

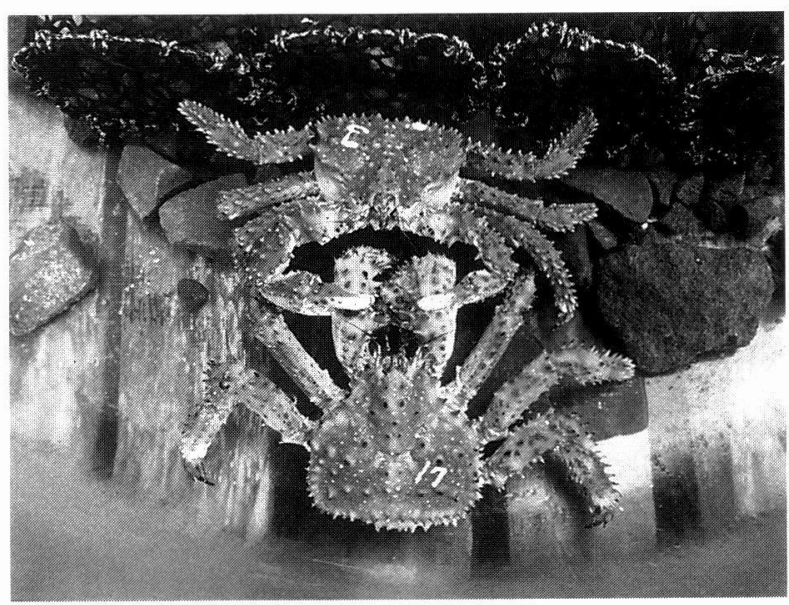

Fig. 1. Precopulatory guarding behavior of the spiny king crab, Paralithodes brevipes. A male (top, \#3) grasps the chelae of a ripe female (bottom, \#17) with its chelae. This behavior lasts for several days through molting of the female, copulation, and spawning. (Photo by M. Ashidate, Japan Sea-Farming Association, Akkeshi Station) 
スが交尾相手になる確率が高まる，間接的に，メスは強い オスを選択していることになる．大型オスの形質の少なく とも一部が遺伝的に決定されているならば，その形質を受 け継ぐことで大型オスを父親にもつ子供は強いオスとして より多くの子供を残すことができるようになる。すなわち， 大型オスによるガードはメスにとっても有利になる.

\section{繁殖生態の共通性}

ここで紹介したハナサキガニの一連の繁殖行動は, 分類 学的に近縁なタラバガニやホンヤドカリ類などの他の異尾 類 (Cunningham et al. 1992) と基本的にはよく似ていること がわかる（丸川 1933; Imafuku 1986; 竹下・松浦 1989; Goshima et al. 1995, 1998; Wada et al., 1995; Minouchi \& Goshima 1998 など).たとえば，1) オスは産卵直前の成熟 メスを抒そらくは性フェロモンを感知することによって識 別することができる，2)成熟入スを見つけると体の一部を はさみ持つガード行動を数日間続ける，3) 大型オスほど ガード行動ならびに交尾行動を成功させやすい，4) ガード しているメスが脱皮した直後に交尾する(メスの脱皮を経 ずに交尾産卵する場合もある)，5) メスは交尾直後に産卵 する，などである。これら基本的な共通点が見られること は, ヤドカリ類など他の異尾類で得られてきた行動生態学 的知見が，ハナサキガニにも適用できる可能性が高いこと を示している. 以下に異尾類で得られた行動生態学的知見 を, 種苗生産と漁場での資源管理に生かす例を紹介しょ j.

\section{種苗生産と行動生態学}

大型甲殼類の種苗生産の現場では, 飼育施設のスペース や人員の制限で多数の親を長期間飼育することは容易では ない，そのような状況では卵を生産するメス親を多く，精 子を提供するオス親を少なく飼育しがちになり，しばしば メスに性比が偏ることが起こる．性比が偏ることによって 雌雄の繁殖行動はどのような影響を受けるのであろうか. 種苗生産現場での実効性比と繁殖成功度の関係を検討して みよう。

\section{種苗生産と実効性比}

性比を偏らせる操作によって，ガード時間の変化とその 後の産卵率の違いを見ることができる.メスの脱皮までの ガード時間をふたつの性比区で比較したところ，雌雄が同 数ずついる水槽の方が, オスが少ない水槽よりも有意に ガード時間が長かった (Wada et al. 2000). オスのライバルが 多い場合には早くからガード行動に入って成熟メスを確保 するとか，あるいは，オスが極端に少ないと脱皮まぎわに しかガード行動に入れない，と解釈できるだろう。後者の 場合だと，最も動きが鈍く，かつ体が柔らかく敵にねらわ れやすい脱皮前後の時期に, メスを守る（ガードする）オ
スがいないことを意味する.

その後の産卵率には驚くべき結果が得られた．雌雄同数 ずついる水槽ではすべてのメスが産卵したが，メスに偏っ た水槽では産卵率のばらつきが大きく，平均産卵率は $70 \%$ にとどまった，平均值には両者で有意差が認められ，雌雄 同数の水槽の方が有意に産卵成功率が高かった (Wada et al. 2000).このことはオスが少ない場合には，正常に産卵でき ないメスが現れることを示唆している.

ハナサキガニの繁殖生態がオスにも多くのコストがかか るシステムで，かつ，メスの産卵期が短期間に同調してい るならば, 1 匹のオスが短い期間に多くのメスと交尾して 受精させることは困難であろう．メスに比べてオスが少な いと, 交尾する相手が必要な時期にいないというオス不足 の状況に陥る危険性もある。種苗生産の現場では，実際に 繁殖に参加する雌雄の比（実効性比という）をあまりにメ スに偏らせてはいけないということである.

\section{雄の繁殖成功度}

少ない親をもとに種苗を生産することによって，必要な 遺伝的多様性を保持しにくいといった問題がある（原田 1999; 谷口 1999). とりあえずこの問題には触れずに以下 の話を進めよう．仮にオスが少なくても，メスの最適交尾 期は個体によってバラつきがあるとか (非同調的)，連続 的に交尾しても正常に受精させる能力がオスに備わってい るならば, オス不足という最悪の事態は回避できるかもし れない.そのためには，1)1匹のオスが連続的になん匹の メスと交尾して正常に受精させることができるか，そして， 2) その能力はオスの体サイズによって異なるのかどうかを 明らかにする必要がある。ささらには, 同じオスを何度か才 ス親（交尾相手）として用いる場合に不可欠な情報である が，3）メスは脱皮後，なん日後まで交尾・産卵が可能なの かを知る必要がある。つまりは脱皮したメスをいつまで交 尾させずに待たせることができるかである．これらの情報 が蓄積されれば，スペースと人員が限られた種苗生産施設 で，飼育すべき拉およそのオス数とその体サイズを決定す ることができるだろう。

ハナサキガニについてのこれら行動生態学的知見は未だ ないが, 類縁のホンヤドカリ類やタラバガニではすでに一 部が明らかになっている．オスの体サイズと繁殖成功率 （相手メスの産卵率で評価）の関係においては, Paul (1992) が報告しているタラバガニの例は大変示唆に富んでいる. 彼によれば，小型オスほど交尾相手メスの産卵率は低いが, その傾向は交尾入ス数が多くなるにつれて強まるという. すなわち，1匹目のメスよりは 2 匹目，3匹目，4匹目とな るにつれ産卵率は低下し, その傾向は小型オスほど顕著で あるという．産卵された卵の受精率で見ると，その傾向は さらに顕著になる。これらの結果は，たとえライバルのオ スがいなくても，小型オスは種苗生産用のオス親としては 適当ではなく，かなりの大型オスでもせいぜい 2 匹程度の 
メスと繁殖させるにとどめるべきであることを意味してい る. タラバガニのオスの繁殖コストが決して低くはないこ とを示している. メスは脱皮後短期間のみ交尾可能で，才 スはそれほど多くのメスを交尾受精させることができない となると，極端にメスに偏った性比で飼育することは潜在 的なメスの繁殖力を十分に発揮させるには好ましくないと 言えよう。

加えて, 十分な数の大型オスがいない種苗生産現場では, 多くのオスが周りにいる場合にはその競争力においてとう てい繁殖に参加できそうもない小型オスさえも, 種苗生産 に用いられている危険性も指摘しておく必要がある。この 小型オスの遺伝的形質が種苗に伝わる問題も考慮すべきだ ろう.さらには, 少ないオスによる遺伝的均一化の問題を 考慮するならば，できるだけ多くのオスといっしょに出会 わせて番わせるのが肝要のようである，今後は，才ス間競 争, メスによるオス選択の強度, その選択基準と適応度の 関係, そして, その遺伝性などを検討する必要があろう.

\section{交尾達九と産卵率}

次に, 交尾可能な状態のメスはいつまで交尾せずに待つ ことができるかを見てみよう。ホンヤドカリの場合, 産卵 まぢかのメスはオスにガードされるが, 交尾前のメスの脱 皮はないことも多い. ホンヤドカリのガードペアをそのま まぺアで飼育した場合と, 引き離してメスのみで飼育して 8 日後にオスを入れた場合とでは，いずれの場合もほぼ 100\%のメスが無事に交尾・産卵した。ところが，ペアを 15 日間引き離した後にいっしょにしても半数のメスは産卵 できなかった（五嶋ら，未発表データ）。これらの結果は, ペア開始後の限られた時間内に交尾すことが正常な産卵に 不可欠であることを示唆している.

類縁の夕ラバガニでも同様の結果が報告されている. メ スの脱皮後 9 日間は, オスと引き合わせれば直ちに交尾し, 正常な産卵を行った.ところが, 10 日目以降は時間経過と ともに産卵率が急激に低下し, 脱皮後 14 日目以降では才 スと出会ってもまったく産卵できなかった (McMullen 1969). これらの結果は, 正常な産卵を実現させるには, 少 なくともメスの脱皮後 9 日間以内にオスと交尾する必要が あることを示している。

ホンヤドカリでも夕ラバガニでも共通して観察されたこ とであるが，脱皮したメスにオスを出会わせると直ちに交 尾・産卵するという事実は，脱皮したてのメスの産卵日を 人為的にコントロールできることを示唆している．脱皮し たメスをオスから引き離しておき，産卵させたい前日ない しは当日にオスと出会わせればよいことになる．もちろん それは脱皮後一定期間内という限定付きではあるが，種苗 生産の現場で作業の効率化に応用できる可能性がある。ま た, タラバガニ類では見られないが（橘高 2000，，他種の 甲款類の種苗生産現場では, 幼稚仔期の共食いが初期死亡 の大きな要因となっている場合がある（たとえば佐々田ら
1986）．共食いを減らす方法のひとつは，産卵・ふ化を同 調させて体サイズのバラツキをできるだけ小さくすること である．人為的に産卵日をコントロールできることは共食 い防止にも応用できる可能性がある．そのためにも，メス の産卵日を同調させるのに見合った十分な数の才スが必要 であることは言うまでもない.

以上の結果は，メスが正常に産卵するためには脱皮後一 定期間内にオスと交尾する必要があることを示唆しており， 極端なオス不足では，産卵できないメスがでる危険性があ ることを示している。

種苗生産を効率的に行うには，ここで明らかになった繁 殖行動が円滑にできる状況を与えることが基本となる．八 ナサキガニの種苗生産の現場では, 実効性比の確保など, その一部はすでに実現化されつつある。

\section{資源管理と行動生態学}

次に漁場における資源管理と行動生態学の関わりを検討 してみよう。漁獲対象サイズを決定する際に，性成熟サイ ズを基準とすることは普通に行われることである．十分に 繁殖させた後に漁獲対象とするのが，漁業資源を永続的に 利用するための基本的な考え方であるとされている(久 保·吉原 1969; Donaldson \& Donaldson 1992 など).この章 では, 成熟サイズと漁獲サイズの推定法, さらには資源の 管理・保全のための漁獲計画の考え方を, 行動生態学との 関係において検討してみよう。

\section{オスの成熟サイズ}

大型甲款類ではメスの成熟サイズをもとめるのは比較的 容易である。多くの種ではメスは産んだ卵を腹部に抱きか かえているので, 繁殖に参加したかどうかが容易に判別で きるからである。

一方オスの成熟サイズは, はさみ脚の幅と甲長の比率の 変化を利用する形態的成熟サイズや (Jewett et al. 1985 な ど), 精巣の成熟を組織学的に判断する生理的成熟サイズ によってもとめられることが多かった（Hinsch 1972; Goshima et al. 1995 など). 形態的成熟サイズは, 成熟個体 の外部形態に発現する二次性徵を検出するもので, 生物を 殺すことなく, 外部から体の一部の長さを測定するだけの 簡便な方法である。その簡便さゆえに，繁殖に関する生物 学的知見が全くない未漁獲種, あるいは未開発漁場で, と りあえずの成熟サイズを推定するために用いられるほとん ど唯一の方法である.

これらの方法によってもとめられた成熟サイズが, 実際 に繁殖に参加しているオスの機能的 (行動的) 成熟サイズ をきちんと反映しているかどうか判断するのはそれほど簡 単ではない. 交尾そのものは短時間で終了することが多い ので, 現場で観察するなどの直接的証拠を得るのが困難だ からである.しかし，繁殖期に見られるガード行動は数日 
Morphometric maturity

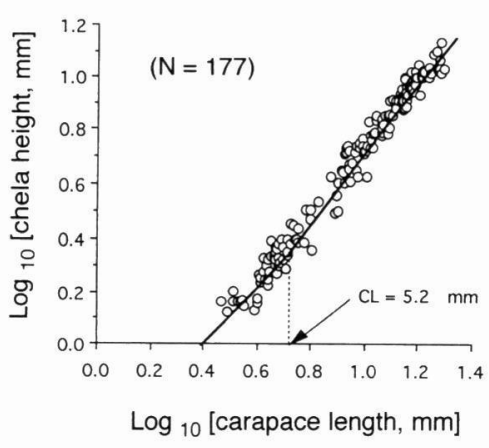

Physiological maturity

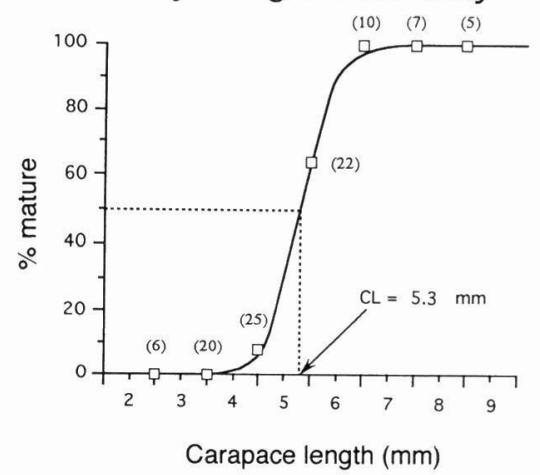

Functional maturity

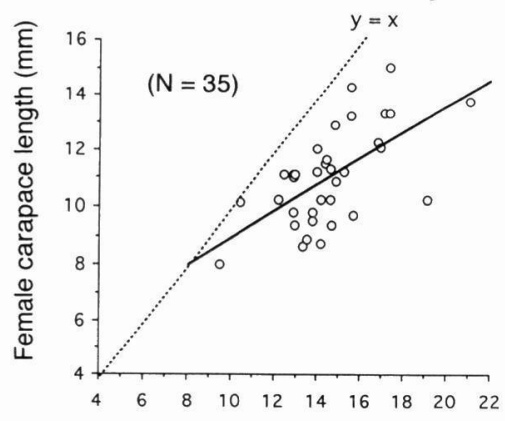

Male carapace length $(\mathrm{mm})$

Fig. 2. Estimates of male maturity size for the stone crab, Hapalogaster dentata, by three different methods. Left: maturity size estimated by the morphometric method. The maturity size corresponds to the size at which the allometric relationship between the sizes of two body parts changes. It is determined from the intersection point on the $\mathrm{X}$-axis at which the juvenile and adult phase-regrerssion lines meet. In this graph, the maturity size is determined from regressions of $\log$ (right chela height, $\mathrm{mm}$ ) on $\log$ (carapace length, $\mathrm{mm}$ ). The estimated size is $5.2 \mathrm{~mm}$ carapace length (broken line). Middle: maturity size estimated by the physiological method. The maturity size is estimated based on histological examination of the gonad and vasa deferentia. A logistic curve is fitted to the percentages of individuals that had ripe spermatozoa in the gonad and vasa deferentia. The size at which $50 \%$ of the individuals become mature is defined as the size of physiological maturity (=5.3 mm carapace length, broken line). Right: functional maturity size, which is defined as the size at which mating begins. This size is estimated by observing mating pairs in the field. The carapace lengths of male and female in guarding pairs are plotted. Note that the smallest maturity size in males by this method ( $9.5 \mathrm{~mm}$ carapace length) is far larger than those estimated by the two other methods. (Modified from Goshima et al. 2000).

間続くので, 交尾そのものよりも目撃できる確率はかなり 高くなる。 そして多くの場合, その後の交尾・産卵に直接 的に結びつく繁殖成功の指標であることが多いので，才ス の機能的成熟サイズを推定するのに有効である.3つの方 法で推定されたオスの成熟サイズが一致しているかどうか を，体が小さいために漁獲対象種ではないが，同じ夕ラバ ガニ科に属するイボトゲガニをモデル生物として検討しよ う (Goshima et al. 2000).

Fig. 2 左には，形態的成熟サイズを推定するために，イ ボトゲガニの甲長とはさみ脚の幅 (いずれも常用対数值) の関係をプロットしている．途中で回帰直線が折れ曲がっ ており，その屈曲点を成熟サイズと見なすのがこの方法で ある，屈曲点はコンピュータープログラムによって数学的 に求められる (Somerton 1980; Somerton \& MacIntosh 1983).

Fig. 2 中は各サイズクラスのオスのうち, 成熟した精子 が精巣と輸精管に認められた個体の割合を示している。便 宜的に 50\%の個体が成熟しているサイズ（SM50 という） を生理的成熟サイズと見なすことが多い。もちろん，生理 的に完全に成熟するのは SM50 值より大きいサイズという ことになる。この場合には甲長 $5.3 \mathrm{~mm}$ が生理的成熟サイ ズ (SM50 值) となり, 形態的成熟サイズ $(5.2 \mathrm{~mm})$ とほぼ 同じ值と推定された。

それでは, 野外で実際に繁殖に参加しているオスのサイ ズはいかほどであろうか？ イボトゲガニのガード行動は, オスがメスの体をはさみ持ったり, 体に覆いかぶさる形で 行われることが多い.そして, メスが脱皮した後に交尾し, その直後に産卵する (Goshima et al. 1995). 八ナサキガニや タラバガニの繁殖行動と酷似している. 野外で観察された
ガードペアはいずれもオスの方がメスの体サイズょりも大 きく, ガード行動を示している最も小さいオスは甲長 $9.5 \mathrm{~mm}$ であった（Fig. 2 右）.

以上の 3 つ方法で推定されたオスの成熟サイズを比較 すると, 前 2 者の值は近いが, 機能的 (行動的) 成熟サイ ズは非常に大きいことがわかる。実際に繁殖に参加してい るオスは, 生理的に成熟しているオスの中でも大型個体で あることが明らかである。これは, メスに比べてあまりに 小さいオスは, ガード行動を行扔うとしてもメスに拒絶さ れたり，仮にガード行動に入ってもより大型オスにメスを 奪い取られたりして, 実際には小型オスが繁殖に成功する 確率は小さいためである。さまざまな種のガード行動に普 遍的に見られる，大型メスによるガード拒絶（メスによる 選択）と, オス間競争の例である（Reid et al. 1994; Jivoff 1997; Sainte-Marie et al. 1997; Wada et al. 1997 など).

\section{オスの成熟サイズと漁獲サイズ}

以上のことは, 形態的, ならびに生理的な情報によって もとめられた成熟サイズは, 実際に繁殖に参加しているオ スサイズよりも過小に推定されている可能性が高いことを 意味している. 同様の例はズワイガニ Chionoecetes opilio でも見られる (Conan \& Comeau 1986).これらの例は，こ れまでの成熟サイズの推定法を基準にして定められた漁獲 規制では, 実際には一度も繁殖に参加したことがない小型 オスさえも漁獲対象になっている危険性があることを示唆 している，オスの成熟サイズ推定にはガード行動を基準と すること，すなわち機能的 (行動的) 成熟サイズをもとに 定めることが望まれる. ズワイガニでは同様の主張が複数 
の研究者によってすでになされている（Elner \& Beninger 1995; 山崎 1996).

ハナサキガニやタラバガニの機能的成熟サイズをもとめ るには，実際に野外でガードペアをたくさん観察して測定 する必要がある。はたしてそれは可能なのだろうか? 前 述のイボトゲガニは潮間帯や浅い潮下帯に生息しているの で，ガードペアを見つけるのはそう困難ではない. しかし， ハナサキガニやタラバガニは水深数十 $\mathrm{m}$ から数百 $\mathrm{m}$ の地 域で, しかも海水温がもっとも低い初春にガード行動を行 う（丸川 1933; 竹下. 松浦 1989）. ゆえに，通常のス キューバによる潜水観察ではとうてい不可能である。おそ らくは，ROV（自走式無人潜水艇）や有人潜水艇を現場に 潜らせて, 実際に野外でガード行動中のペアを採取して体 サイズを測定するほかないだろう。アラスカのオオズワイ ガニ Chionoecetes bairdi では，すでにそのような調査研究 が行われている (Stevens et al. 1993). 潜水艇を使う調査に は多くの労力と資金が必要である. しかも，資源レベルが かなり低下している現状では，現場でガードペアを見つけ るのは容易ではないかもしれない.しかし, 資源回復と安 定生産のための根本的な解決に近道はなく, 基本的な繁殖 生態を明らかにすることからはじめる他はないだろう。多 くの大型甲殼類について資源の枯渴が危惧されている現状 では一刻の猶予もなく，早急に着手すべき調査項目である。

\section{漁獲と実効性比}

漁獲と行動生態学の関係でもうひとつ触れる必要がある のは，漁獲計画に関してである．漁場に残された雌雄が正 常な繁殖行動を実現できる程度の個体数と実効性比を確保 するように漁獲性比と漁獲量を決定するなど，漁場におけ る資源管理計画にも応用できるかもしれない.

上記のイボトゲガニのオスの成熟サイズの検討は, 漁獲 が全く行われていない状況下のものである．現実には大型 甲款類漁業の多くは，オスのみを漁獲対象としていること が多い（漁業調整規則など）。その場合は漁獲によって大 型オスが少なくなるため, 生理的成熟サイズには達してい るものの，通常なら繁殖に参加できない小型オスさえも ガード行動に参加することが予想される. その例はすでに アラスカのズワイガニ資源において報告されている (Ennis et al. 1988, 1990). また，ケガニではガードペアは必ずオス の方がメスよりも体サイズが大型であるという（佐々木 . 上田 1992). しかし，野外で見られる大型メスには交尾を おこなったことを示す交尾栓が見られないメスも相当割合 いるという（佐々木 1995）. 大型メスに見合う大型オスが 少ないことを示唆しているのかもしれない.オスのみを漁 獲する現行規制では避けられない現象かも知れない。一方, ホクヨウイチョウガニ (Cancer magister) では, 仮に大型メ スに見合う大型オスが不足して，大型メスが交尾産卵でき なくても, 個体群全体の潜在的産卵数の減少はたいしたこ とはないだろうという推定結果もある (Hankin et al. 1997).
いずれの例も，両性に対する漁獲圧の違いによって漁場 に残された雌雄の個体数と実効性比が偏り，そのことがオ スの行動的成熟サイズを変化させることを示している．こ のことは，同種でさえも漁場が異なることによって，ある いは同一漁場においてさえも漁獲圧が異なることによって 機能的成熟サイズが変化することを意味する．それぞれの 漁場において，たとえオスのみが漁獲対象になっている場 合でも，定期的に雌雄両性の体サイズ組成と実効性比を調 査し，実際に繁殖に参加しているオスのサイズを確認する ことによって，漁獲計画を見直す必要があることを意味し ている。そうでないとすべてのメスの産卵を十分に保証で きない事態を引き起こすことも考えられる．潜在的なメス の繁殖量（産卵数）を実現させるのに支障がない程度に， 残すべきオスのサイズと個体数を決定する必要があるだろ う。そのような観点から，ズワイガニでは適正性比を実現 するための漁獲法が検討されている（山崎 2000）。

さらには，種苗生産の場合と同様に遺伝的問題も考慮す る必要がある．漁獲圧がかからない本来の状況なら，とう てい参加できないほどの小型オスが繁殖に参加し，その小 型才スの遺伝的形質が子供に伝わることが, 残された個体 群に対していかなる事態を引き起こすのか, 遺伝的意味合 いも十分に考慮する必要があるだろう．上記のホクヨウイ チョウガニの例でも，小型オスの遺伝的形質が次世代に伝 わるデメリットはなにも考慮されていない.この問題解決 には, 行動生態学, 個体群生態学, 集団遺伝学の要素を組 み入れたモデルを構築して, 残すべき個体の最適なサイズ と個体数をもとめ，それに基づいて最適な漁獲計画を立て るべきだろう。

オスのみが漁獲対象となってきたこれまでの漁獲規制が， 必要な実効性比の確保に有効であったのか, オスの漁獲サ イズは実際に繁殖に参加できるオスサイズを満たしていた のか，はたしてガード行動を含む大型甲款類の正常な繁殖 行動を保証できる状況にあったのか, 行動生態学的知見を もとに検証されるべきであろう。

\section{おわりに}

ここに紹介した行動生態学的知見は，水産増殖，栽培漁 業に関係するほんの一部にすぎない.さまざまな動植物を 対象に蓄積されてきた行動生態学のこれまでの知見が，漁 業に応用できる範囲は決して小さくはないだろう。繁殖行 動のプロセスと機能をきちんと解明することによって得ら れる行動生態学的知見を，種苗生産や資源管理という現場 に応用することは大いに有効であり，今後ますますその必 要性が増すものと言える。ここで紹介した例は，基礎的知 見が応用面には必要であるという当たり前のことが確認さ れたにすぎない.しかし，それが行動生態学というまさに 「食えない」基礎学が実は有効であるという意味で，応用 学分野に所属しながら行動生態学に携わっている方々に, 
今後の期待を込めて熱いエールを送りたい．「役に立たな い研究」などないのである.

今後, 行動生態学的アプローチの有効性はより多くの分 野で認識されるだろうし，また積極的に導入をはかるべき であろう。この拙文がそのきっかけになれば幸いである。

謝 辞: 本稿で紹介したハナサキガニやホンヤドカリの結果は, 筆者が所属している北海道大学水産学部の多くの大学院生, 学生 諸氏との共同研究の成果をもとにしている．特に，和田 哲，吉 野健児，金澤正治，佐藤 环の諸氏には野外調査，観察，実験で 大変打世話になった。また，日本栽培漁業協会厚岸事業場の錦昭 夫場長, 芦立昌一氏には八ナサキガニの実験・観察に, 施設の利 用，材料提供とさまざまな協力をいただいた。その協力なしでは とうてい実験の遂行はできなかった，厚く御礼申し上げる，千葉 晋, 吉野健児の両氏には原稿を読んでいただき，建設的な助言を いただいた。記して感謝申し上げる。

\section{引用 文 献}

Conan, G. Y. and M. Comeau 1986. Functional maturity and terminal molt of male snow crab, Chionoecetes opilio. Canadian Journal of Fisheries and Aquatic Sciences, 43: 1710-1719.

Cunningham, C. W., N. W. Blackstone and L. W. Buss 1992. Evolution of king crab from hermit crab ancestors. Nature, 355: 539-542.

Donaldson, W. E. and W. K. Donaldson 1992. A review of the history and justification for size limits in Alaskan king, Tanner, and snow crab fisheries. Alaska Department of Fish and Game, Division of Commercial Fisheries, Fishery Research Bulletin 92-02, Juneau. 21 pp.

Elner, R. W. and P. G. Beninger 1995. Multiple reproductive strategies in snow crab, Chionoecetes opilio: Physiological pathways and behavioral plasticity. Journal of Experimental Marine Biology and Ecology, 193: 93-112.

Ennis, G. P., R. G. Hooper and D. M. Taylor 1988. Functional maturity in small male snow crabs (Chionoecetes opilio). Canadian Journal of Fisheries and Aquatic Sciences, 45: 2106-2109.

Ennis, G. P., R. G. Hooper and D. M. Taylor 1990. Changes in the composition of snow crab (Chionoecetes opilio) participating in the annual breeding migration in Bonne Bay, Newfoundland. Canadian Journal of Fisheries and Aquatic Sciences, 47: 2242-2249.

Goshima, S., K. Ito, S. Wada, M. Shimizu and S. Nakao 1995. Reproductive biology of the stone crab Hapalogaster dentata (Anomura: Lithodidae). Crustacean Research, 24: 8-18.

Goshima, S., T. Kawashima and S. Wada 1998. Mate choice by males of the hermit crab Pagurus filholi: Do males assess ripeness and/or fecundity of females? Ecological Research, 13: 151-161.

Goshima, S., M. Kanazawa, K. Yoshino and S. Wada 2000. Maturity in male stone crab, Hapalogaster dentata, and its application for fishery management. Journal of Crustacean Biology, 20: 641-646.

Hankin, D. G., T. H. Butler, P. W. Wild and Q. L. Xue 1997. Does intense fishing on males impair mating success of female Dungeness crabs? Canadian Journal of Fisheries and Aquatic Sciences, 54: 655-669.

原田泰志 1999. 野生集団への遺伝的影響の小さい種苗生産. 放流 方策の数理的研究. 水産育種, 27: 15-31.

Hinsch, G. W. 1972. Microtubules in the sperm of the spider crab, Libinia emarginata. Journal of Ultrastructure Research, 29: 525-534.

農林水産省北海道統計情報事務所 2000 . 平成 11 年北海道漁業の 動き, 北海道農林水産統計年報 (水産編), 札幌. $168 \mathrm{pp}$.

Imafuku, M. 1986. Sexual discrimination in the hermit crab Pagurus geminus. Journal of Ethology, 4: 39-47.

Jewett, S. C., N. A. Sloan and D. A. Somerton 1985. Size at sexual matu- rity and fecundity of the fjord-dwelling golden king crab Lithodes aequispina. Journal of Crustacean Biology, 5: 377-385.

Jivoff, P. 1997. Sexual competition among male blue crab, Callinectes sapidus. Biological Bulletin, 193: 368-380.

北島 力 (編) 1993. 放流魚の健苗性と育成技術。恒星社厚生 閣, 東京, $119 \mathrm{pp}$.

橘高二郎 2000. タラバガニ・ハナサキガニの生物学的特性とその 資源培養における意義。橘高二郎・出口吉昭・平田八郎・山崎 文雄 (共編), 水産業の再生戦略一冷水域からの発信, 恒星社 厚生閣, 東京, pp. 83-110.

Krebs, J. R. and N. B. Davies 1981. An Introduction to Behavioural Ecology. Blackwell, London. 292 pp. (城田安幸 ·上田恵介（訳) 1984. 行動生態学を学ぶ人に, 蒼樹書房, 東京)

久保伊津男・吉原友吉 1969 . 水産資源学. 共立出版, 東京, 482 $\mathrm{pp}$.

丸川久俊 1933. たらばがに調査. 水産試験場報告, 4:1-152.

McMullen, J. C. 1969. Effects of delayed mating on the reproduction of king crab, Paralithodes camtschatica. Journal of Fisheries Research Board of Canada, 26: 2737-2740.

Minouchi, S. and S. Goshima 1998. Effect of male/female size ratio on mating behavior of the hermit crab Pagurus filholi (Anomura: Paguridae) under experimental conditions. Journal of Crustacean Biology, 18: 710-716.

Paul, A. J. 1992. A review of size at maturity in male Tanner (Chionoecetes bairdi) and king (Paralithodes camtschaticus) crabs and the methods used to determine maturity. American Zoology, 32: 534-540.

Reid, D. G., P. Abello, C. G. Warman and E. Naylor 1994. Size-related mating success in the shore crab Carcinus maenas (Crustacea: Brachyura). Journal of Zoology, London, 232: 397-407.

Ridley, M. 1983. The Explanation of Organic Diversity. Clarendon Press, Oxford, 272 pp.

Sainte-Marie, B., J. M. Sevigny and Y. Gauthier 1997. Laboratory behavior of adolescent and adult males of the snow crab (Chionoecetes opilio) (Brachyura: Majidae) mated noncompetitively and competitively with primiparous females. Canadian Journal of Fisheries and Aquatic Sciences, 54: 239-248.

佐々田昭七・松村史朗・北島 力 1986. ガザミの中間育成におけ る共食い防止について. 栽培漁業技術開発研究, 15: 51-56.

佐々木 潤 1995. 交尾栓保有率から推定した道東太平洋における ケガニErimacrus isenbekii (Brandt) 雌の性的成熟サイズ (短報). 北海道水産試験場研究報告, 46: 19-21.

佐々木 潤・上田吉幸 1992. 天然から採集されたケガニの配偶サ イズ.甲款類の研究, $21: 147-152$.

Somerton, D. A. 1980. A computer technique for estimating the size of sexual maturity in crabs. Canadian Journal of Fisheries and Aquatic Sciences, 37: 1488-1494.

Somerton, D. A. and R. A. MacIntosh 1983. The size at sexual maturity of blue king crab, Paralithodes platypus, in Alaska. Fisheries Bulletin, 81: 621-628.

Stevens, B. G., W. E. Donaldson, J. A. Haaga and J. E. Munk 1993. Morphometry and maturity of paired Tanner crabs, Chionoecetes bairdi, from shallow- and deepwater environments. Canadian Journal of Fisheries and Aquatic Sciences, 50: 1504-1516.

竹下貢二・松浦修平 1989. 北太平洋のタラバガニーI 生殖と成長. 栽培漁業技術開発研究, 18: 35-43.

谷口順彦 1999. 魚介類の遺伝的多様性とその評価法. 海洋と生 物, 21:280-289.

Wada, S., S. Goshima and S. Nakao 1995. Reproductive biology of the hermit crab Pagurus middendorffii Brandt (Decapoda: Anomura). Crustacean Research, 24: 23-32.

Wada, S., M. Ashidate and S. Goshima 1997. Observations on the reproductive behavior of the spiny king crab Paralithodes brevipes (Anomura: Lithodidae). Crustacean Research, 26: 56-61.

Wada, S., M. Ashidate, K. Yoshino, T. Sato and S. Goshima 2000. The 
reproductive biology of the spiny king crab Paralithodes brevipes (Anomura: Lithodidae): the effects of sex ratio on the spawning frequency and mating behavior. Journal of Crustacean Biology, 20: 479482.

山村則男 1986. 繁殖戦略の数理モデル. 東海大学出版会, 東京,
$177 \mathrm{pp}$. 山崎＼cjkstart淳 1996. 日本海における雄ズワイガニの漁獲サイズ．日本 水産学会誌, 62: 623-630.

山崎 淳 2000. 日本海西部ズワイガニ漁業における適正性比を実 現するための水ガニの漁獲方法. 日本水産学会誌, 66: 221-227. 